\title{
The concept of sustainable development: environmental aspects and project approach
}

\author{
Natalia Kataeva ${ }^{1, *}$, Alexey Sysolyatin ${ }^{1}$, Oksana Feoktistova $^{2}$, and Darya Starkova $^{3}$ \\ ${ }^{1}$ Vyatka State University, Moskovskaya street, 36, Kirov, 610000, Russia \\ ${ }^{2}$ Moscow State Technical University of Civil Aviation, 20, Kronshtadtsky blvd, Moscow, 125993, \\ Russia \\ ${ }^{3}$ Vyatka State Agrotechnological University, Oktyabrsky avenue, 133, Kirov, 610017, Russia
}

\begin{abstract}
This article analyzes the environmental aspects of sustainable regional and macroeconomic development, as well as the impact of environmental factors and national environmental projects. The essence of the concept of sustainable development of economic entities in a broad sense is to ensure stable growth of indicators in the environmental, social and economic spheres in the long term. Based on the analysis of the list of indicators of sustainable development, the increasing role of the environmental component is shown. We have identified particularly acute environmental problems that hinder effective sustainable development both at the micro-level (of the organization) and at the macro-level in the whole country and the global community. Based on the calculation of the nature protection, socio-ecological and industrial-ecological indices, the consolidated environmental rating and the place of the Kirov region is determined in it. The analysis of the results of research and the opinions of the World Economic Forum experts on the problems of global threats showed the timeliness and relevance of the national project "Ecology" being implemented in Russia, as well as measures of environmental support and planned environmental projects in the Kirov region. The implementation of the planned measures will activate the catalysts of sustainable development and reduce the risks of negative impact on the environment.
\end{abstract}

\section{Introduction}

In most countries of the world, the issue of environmental conservation requires special attention from competent national as well as international departments in connection with climate change in recent decades.

Let alone the environment, whether in the political and business circles or in the media, not a week, not even a day. This concern mainly reflects the regulatory needs expressed by society, especially with regard to the impact of the day-to-day operations of enterprises on the physical environment. Pressure on industrial organizations from local residents and

\footnotetext{
*Corresponding author: Natalya-kataeva@yandex.ru
} 
organizations in the field of protection and environmental protection is increasing. Therefore, business adjusts its strategic decisions in accordance not only with economic rationality, but also with social and environmental reality.

As a result of such pressure from all stakeholder groups, countries are forced to take measures of changing the methodological approaches to environmental project management in order to bring them into line with existing requirements.

The purpose of the study is to analyze the environmental aspects of the sustainable development concept, trends in environmental indicators and the degree of their implementation in the strategy of sustainable development of Russia, which has an undoubted impact on the environmental safety of countries and regions.

Level of development of the scientific problem. The theoretical foundations for studying environmental safety are laid in the works of V. I. Vernadsky, I. I. Dedyu, Yu. K. Efremov, A. P. Kapitsa, Yu. N. Kurazhkovsky, A. A. Mints, N. F. Reimers, T. S. Khachaturov, and others. [1,2,3]. The problem of environmental safety assessment is discussed in the works of domestic (S. N. Bobylev, I. I. Veselova, E. Ya. Vlasova, A.D. Dumnov, N. G. Rybalsky, I. N. Rubanov) and foreign scientists (Jiang Mingjun, J. Barnett, K. Hamilton, J. Dixon, L. MoE, P. R. Ehrlich, etc.) [1,2]/

Problems of regional economy management, assessment and using of regional resources were considered in the works of such scientists as: V. N. Afanasyev, I. A. Boyko, A. L. Gaponenko, S. Yu. Glazyev, Yu. S. Dulshikov, I. P. Ivanitskaya [3].

However, a number of issues related to the identification of environmental aspects in the blocks of indicators of the sustainable development concept remain unaffected. Some indicators that characterize environmental aspects are included in the sections that indirectly relate to the environment.

\section{Materials and methods}

The emergence of the sustainable development concept led to the prerequisites that can be conditionally divided into social, economic, and environmental.

The essence of the concept of sustainable development of economic entities in a broad sense is to ensure stable growth of indicators in the environmental, social and economic spheres in the long term, starting from the micro level (organization) and ending with the macro level (region, state and the world community as a whole).

The environmental aspect is aimed at protecting the environment and maintaining the ecological balance by controlling the technologies used by the economic entity.

The implementation of the sustainable development strategy involves: the development of a system of indicators that allow monitoring the degree of achievement of the set goals, identifying trends, timely diagnosis of problems, as well as justification of evaluation criterions.

The sustainable development (SD) indicators are designed to meet the following objectives (Figure 1). 


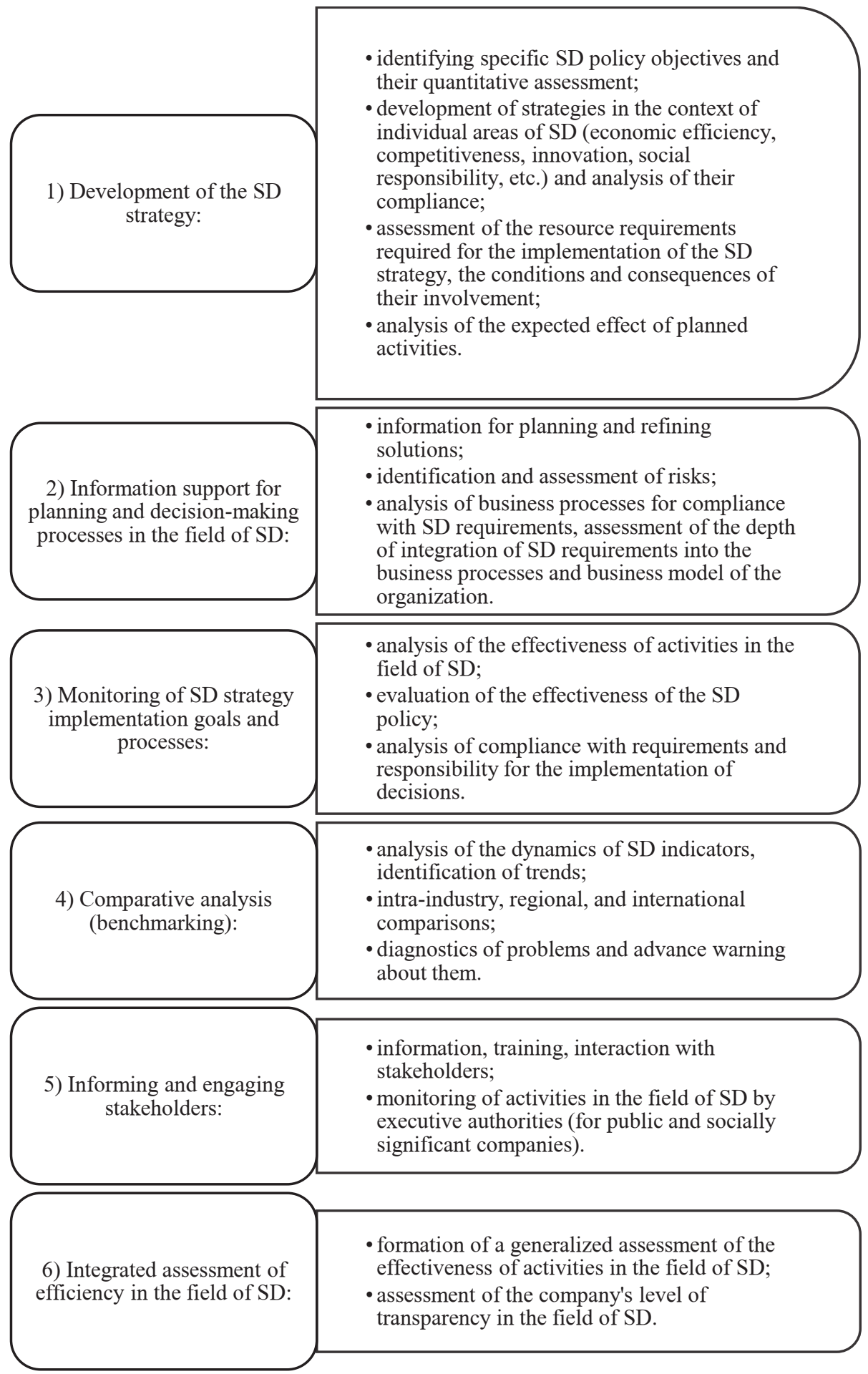

Fig. 1. Objectives of the sustainable development strategy. 
SD indicators allow you to specify the goals that follow from the adopted strategy. This makes it possible to set a number of targets for each indicator, thus providing a clearer vision and understanding of the overall SD policy objectives. In addition, SD indicators provide tools for assessing the progress of strategy implementation at various levels of the company's management (linear and functional). They provide an opportunity to monitor, evaluate and analyze the effectiveness of SD activities and, if necessary, adjust the overall policy to meet emerging new challenges. This also allows to distribute and assign responsibility for achieving SD targets to different departments, which becomes the basis for motivation in turn.

Individual SD indicators of the economic entities can be used to provide information support for planning and decision-making processes at the regional and state levels. For example, SD indicators can be used as a basis for assessing the long-term sustainability of programs for implementing socio - economic measures in regions.

Indicators (indicators) of sustainable development are usually grouped in the context of economic, social and environmental components.

The economic component of sustainable development is determined by the factors of rational usage of resources, ensuring financial stability, competitiveness of products or services, and innovation activity.

The factors of development of own team (labor safety; stable payment of wages; additional medical and social insurance of employees; development of human resources through training programs, training and advanced training; maintaining the image of a socially responsible employer), as well as participation in social investments through their internal and external social programs in the territories of their presence, focused on maintaining their social well-being, safety and sustainability, determine the social aspects of sustainable development.

The environmental sustainability of an economic entity is determined by its activity to protect and restore the environment, including reducing harmful emissions and other environmental pressures.

Indicators of environmental sustainability reflect the characteristics of the economic entity's impact on living and non-living nature, including ecosystems, land, air and water. Of all the three components of sustainable development and the corresponding reporting on the environmental component, the greatest unity of views has been achieved. It is important to provide information about environmental sustainability in both absolute and relative terms for a full and objective assessment of the external environment risks of an economic entity.

Absolute values reflect the scale (magnitude) of the impact or use of resources, which allows us to consider the performance of an economic entity in the context of the large systems in which it operates. Relative performance measures make it possible to conduct a comparative analysis of different scales economic entities.

Of the 17 sustainable development goals (SDG), only three of them directly assess environmental aspects, and it is proposed to include group 12 as indirect environmental indicators that correspond to the sustainable development goals. Responsible consumption and production and a number of indicators from other SDG blocks (table 1).

Table 1. Environmental indicators in the group of the SDG.

\begin{tabular}{|c|c|c|c|c|}
\hline \multicolumn{3}{|c|}{ SDG environmental indicators (direct) } & \multicolumn{2}{|c|}{ SDG environmental indicators (indirect) } \\
\hline $\begin{array}{c}13 . \\
\text { Climate } \\
\text { action }\end{array}$ & $\begin{array}{l}\text { 14. Life below } \\
\text { water }\end{array}$ & 15. Life on land & $\begin{array}{l}\text { 12. Responsible } \\
\text { consumption } \\
\text { and production }\end{array}$ & Other groups of the SDG \\
\hline $\begin{array}{l}\text { Energy- } \\
\text { related } \\
\mathrm{CO}_{2}\end{array}$ & $\begin{array}{l}\text { Mean area that } \\
\text { is protected in } \\
\text { marine sites }\end{array}$ & $\begin{array}{l}\text { Mean area that } \\
\text { is protected in } \\
\text { terrestrial sites }\end{array}$ & $\begin{array}{c}\text { Municipal solid } \\
\text { waste }\end{array}$ & $\begin{array}{c}\text { 2. Zero hunger: } \\
\text { Cereal yield } \\
\text { Sustainable Nitrogen }\end{array}$ \\
\hline
\end{tabular}




\begin{tabular}{|c|c|c|c|c|}
\hline emissions & $\begin{array}{l}\text { important to } \\
\text { biodiversity }\end{array}$ & $\begin{array}{l}\text { important to } \\
\text { biodiversity }\end{array}$ & & Management Index \\
\hline $\begin{array}{c}\mathrm{CO}_{2} \\
\text { emissions } \\
\text { embodied } \\
\text { in imports }\end{array}$ & $\begin{array}{l}\text { Ocean Health } \\
\text { Index: Clean } \\
\text { Waters score }\end{array}$ & $\begin{array}{l}\text { Mean area that } \\
\text { is protected in } \\
\text { freshwater sites } \\
\text { important to } \\
\text { biodiversity }\end{array}$ & Electronic waste & $\begin{array}{c}\text { 6. Clean water and } \\
\text { sanitation: } \\
\text { Freshwater withdrawal } \\
\text { Anthropogenic } \\
\text { wastewater that receives } \\
\text { treatment } \\
\text { Scarce water } \\
\text { consumption embodied } \\
\text { in imports } \\
\end{array}$ \\
\hline \multirow[t]{4}{*}{$\begin{array}{c}\mathrm{CO}_{2} \\
\text { emissions } \\
\text { embodied } \\
\text { in fossil } \\
\text { fuel } \\
\text { exports }\end{array}$} & $\begin{array}{l}\text { Fish caught } \\
\text { from } \\
\text { overexploited } \\
\text { or collapsed } \\
\text { stocks }\end{array}$ & $\begin{array}{l}\text { Red List Index } \\
\text { of species } \\
\text { survival }\end{array}$ & $\begin{array}{l}\text { Production- } \\
\text { based } \mathrm{SO}_{2} \\
\text { emissions }\end{array}$ & $\begin{array}{l}\text { 7. Affordable and clean } \\
\text { energy: } \\
\mathrm{CO}_{2} \text { emissions from fuel } \\
\text { combustion for } \\
\text { electricity and heating } \\
\text { per total electricity } \\
\text { output }\end{array}$ \\
\hline & $\begin{array}{l}\text { Fish caught by } \\
\text { trawling }\end{array}$ & $\begin{array}{c}\text { Permanent } \\
\text { deforestation }\end{array}$ & $\begin{array}{c}\mathrm{SO}_{2} \text { emissions } \\
\text { embodied in } \\
\text { imports }\end{array}$ & $\begin{array}{l}\text { 11. Sustainable cities } \\
\text { and communities: } \\
\text { Annual mean } \\
\text { concentration of } \\
\text { particulate matter of less } \\
\text { than } 2.5 \text { microns in } \\
\text { diameter (PM2.5) } \\
\text { Access to improved } \\
\text { water source, piped }\end{array}$ \\
\hline & $\begin{array}{c}\text { Marine } \\
\text { biodiversity } \\
\text { threats } \\
\text { embodied in } \\
\text { imports }\end{array}$ & $\begin{array}{l}\text { Terrestrial and } \\
\text { freshwater } \\
\text { biodiversity } \\
\text { threats } \\
\text { embodied in } \\
\text { imports } \\
\end{array}$ & $\begin{array}{l}\text { Production- } \\
\text { based nitrogen } \\
\text { emissions }\end{array}$ & \\
\hline & & & $\begin{array}{c}\text { Nitrogen } \\
\text { emissions } \\
\text { embodied in } \\
\text { imports }\end{array}$ & \\
\hline
\end{tabular}

Currently, Russia ranks 57th in the sustainable development rating with a score of 71.92 points [4]. At the same time, it should be taken into account that a number of indicators are measured at intervals of several years, which does not always reflect the real situation. Currently, Russia is implementing a number of national projects aimed at achieving the SDG indicators, including the national project "Ecology". The first interim results show the effectiveness of the measures taken to achieve the SDG indicators.

Theoretical and methodological basis was the conceptual research of the main provisions of micro- and macroeconomics, interrelations between their elements, based on the usage of modern achievements and innovative approaches to rational use of natural resources in order to create a competitive and socially responsible system of natural resources management, as well as research on financial and organizational problems of sustainable development of the region based on environmental indicators, analytical and expert methods, presented in domestic and foreign scientific literature.

The study used data presented in the Global Risk Report, which was obtained by interviewing about 800 global experts and decision makers. Respondents were asked to assess global threats in terms of their likelihood of occurrence and the extent of their 
impact. All existing global risks were divided into five categories: economic, environmental, geopolitical, social and technological [5].

A rating system, based on the conceptual scheme for the emergence of the noosphere proposed by V. I. Vernadsky, was used to assess environmental well-being. The logic for determining the rating was based on the principles of sustainable development in accordance with the UN Declaration on environment and development using the expert method. The group of experts evaluated events in three areas: ecosphere (environmental index), technosphere (industrial and environmental index), and society (social and environmental index). Each index was evaluated by seven indicators, which in turn were evaluated depending on the nature of the event with the numeric values +1 - positive rating, -1 - negative rating. To compare regions, the relation of positive and negative ratings is automatically converted to a 100 -point scale. The calculation is made online based on a single mathematical model [6].

Justification of the main provisions of the process of regional reforestation was carried out using methods of deduction and induction, abstract - logical judgments and evaluations, a systematic and integrated approaches. The empirical part of the work is based on the use of monographic methods of information analysis [3].

\section{Results}

Today, our country pays great attention to the environment. The development of laws in the area of environmental protection and the regular updating of requirements in the field of environmental control, obliges each company to follow these rules for the functioning of its activities.

Currently, issues related to $\mathrm{CO} 2$ emissions are being actively addressed, measures are being taken to reduce threats to marine biodiversity, the state has tightened control over deforestation, and the list of protected sites important for biodiversity has been expanded.

Environmental (environmental protection) projects are a special type of investment projects, which are distinguished by their clear focus on environmental protection, as well as the rational use of natural resources. Ecological projects are projects aimed at reducing the impact of anthropogenic activities on the environment and maintaining the quality of the environment. The many features and diversity of environmental activities and projects make it necessary to systematize and classify environmental investments.

Numerous publications of the authors on this topic indicate the relevance of the problem under study. However, the increasing number of environmental and related economic problems, the development of science and technology, the emergence of new technologies in the field of waste and other pollution management, new organizational forms of project implementation and other factors lead to the need for expansion and supplement the existing classifications of environmental projects and related investments. Figure 2 shows the classification of environmental projects by their effectiveness. 


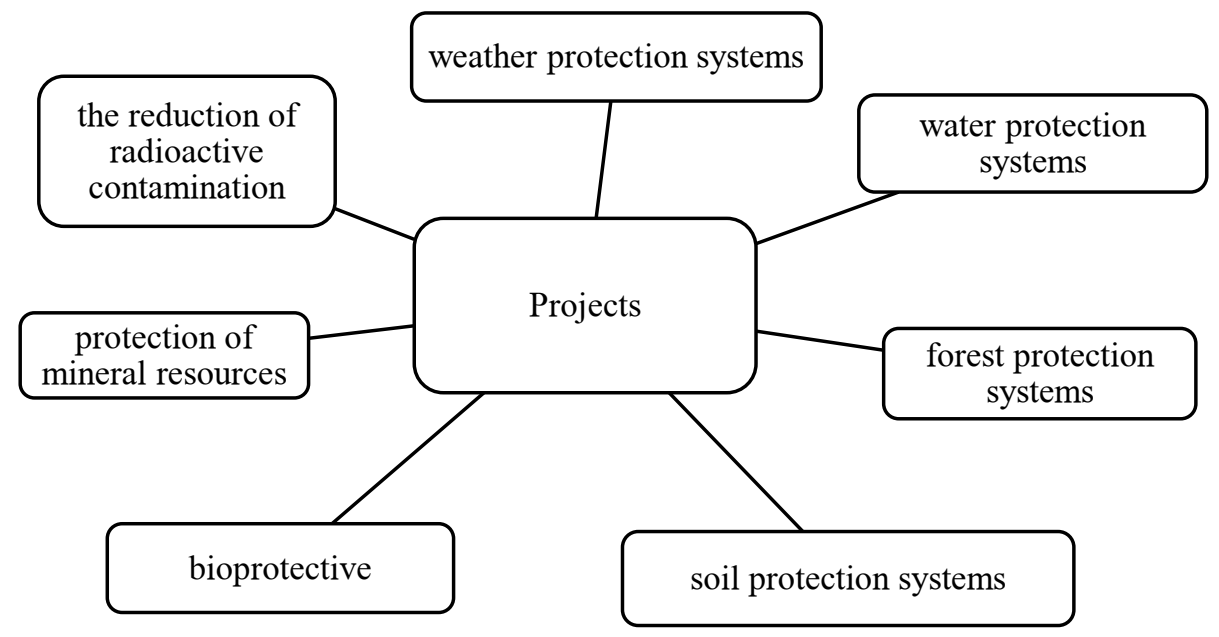

Fig. 2. Classification of projects by environmental outcome.

To implement the basic provisions of the concept of sustainable development in the area of ecology, the national project "Ecology" is being implemented in Russia».

The work on the national project aimed at environmental protection is carried out in five areas: waste disposal and recycling, preservation of water bodies and improvement of drinking water quality, reduction of air pollution, protection of nature and animals, introduction of the best environmental technologies [7] (table 2).

Table 2. Components of the national project «Ecology» [8].

\begin{tabular}{|c|c|}
\hline Federal project & $\begin{array}{l}\text { The essence of the project } \\
\end{array}$ \\
\hline Clean country & $\begin{array}{l}\text { By 2024, almost } 200 \text { unauthorized landfills within the city limits will } \\
\text { cease to exist. } 75 \text { of the most dangerous objects of accumulated } \\
\text { environmental damage will be eliminated. }\end{array}$ \\
\hline $\begin{array}{l}\text { Integrated } \quad \text { solid } \\
\text { municipal } \quad \text { waste } \\
\text { management system }\end{array}$ & $\begin{array}{l}\text { The most important part of the national project will be a fundamentally } \\
\text { new system of solid municipal waste management: } 60 \% \text { of household } \\
\text { waste will be used for recycling in } 2024 \text {, compared to } 7 \% \text { in } 2018 \text {, } \\
\text { including } 36 \% \text { for recycling. } \\
\text { For this purpose, separate collection of garbage by citizens and } \\
\text { enterprises will be established, waste disposal and recycling plants will } \\
\text { be put into operation. }\end{array}$ \\
\hline $\begin{array}{l}\text { Infrastructure for } \\
\text { waste management of } \\
\text { hazard classes I-II }\end{array}$ & $\begin{array}{l}7 \text { production and technical complexes will be built for the disposal of } \\
\text { waste of hazard class I and II (Class I - mercury-containing waste, } \\
\text { class II- rechargeable batteries). A unified state information system for } \\
\text { accounting and control of such waste is being created. }\end{array}$ \\
\hline Clean air & $\begin{array}{l}\text { In } 12 \text { industrial cities - Bratsk, Krasnoyarsk, Lipetsk, Magnitogorsk, } \\
\text { Mednogorsk, Nizhny Tagil, Novokuznetsk, Norilsk, Omsk, } \\
\text { Chelyabinsk, Cherepovets and Chita - comprehensive measures are } \\
\text { being taken to reduce emissions into the atmosphere. } \\
\text { Значительную роль в проекте играет создание системы контроля } \\
\text { и мониторинга за выбросами загрязняющих веществ с крупных } \\
\text { промышленных предприятий. }\end{array}$ \\
\hline $\begin{array}{l}\text { Improving the Volga } \\
\text { River }\end{array}$ & $\begin{array}{l}\text { The banks of the Volga will be cleared of garbage, new wastewater } \\
\text { treatment facilities will be built, and hydraulic structures will be } \\
\text { reconstructed. It is planned to clear and deepen the bottom in the ways }\end{array}$ \\
\hline
\end{tabular}




\begin{tabular}{|c|c|}
\hline & $\begin{array}{l}\text { of fish movement, as well as to lift and dispose of } 95 \text { ships that sank in } \\
\text { the Volga water area. }\end{array}$ \\
\hline $\begin{array}{l}\text { Preservation of Lake } \\
\text { Baikal }\end{array}$ & $\begin{array}{l}\text { Taking care of Lake Baikal has become a separate area of the national } \\
\text { project. As part of it, new wastewater treatment facilities will be } \\
\text { modernized and built, and a significant reduction in polluted areas near } \\
\text { the lake is planned. } \\
\text { It is impossible to preserve Lake Baikal without the support of its } \\
\text { biological diversity. It is planned to populate the reservoir with } \\
\text { millions of omul and sturgeon fry. }\end{array}$ \\
\hline $\begin{array}{l}\text { Preservation of } \\
\text { unique water bodies }\end{array}$ & $\begin{array}{l}\text { Work is underway to improve the ecological condition of many lakes, } \\
\text { reservoirs and rivers. These include the Teletskoye, Ladoga, and Onega } \\
\text { Lakes, the Volga, Don, and Yenisei Rivers, and others. It is planned to } \\
\text { achieve the result by cleaning the coast from garbage and improving } \\
\text { the coastal waters. }\end{array}$ \\
\hline $\begin{array}{l}\text { Conservation of } \\
\text { biological diversity } \\
\text { and development of } \\
\text { ecological tourism }\end{array}$ & $\begin{array}{l}\text { According to the national project, the number of rare and endangered } \\
\text { species of animals is being restored. } \\
\text { At least } 24 \text { new specially protected natural areas will be created in the } \\
\text { country, the total area of protected areas will grow by } 5 \text { million } \\
\text { hectares, and the number of tourists visiting them will reach almost } 8 \\
\text { million people due to the creation of infrastructure for eco-tourism. }\end{array}$ \\
\hline Forest conservation & $\begin{array}{l}\text { The area of annual forest planting will be equal to the area of } \\
\text { deforested and dead forests. The regions will be } 100 \% \text { provided with } \\
\text { forest fire equipment, which will reduce the damage from forest fires } \\
\text { by } 2.6 \text { times. It is also planned to equip large-scale forest areas with } \\
\text { special equipment for reforestation. }\end{array}$ \\
\hline $\begin{array}{l}\text { Implementing the best } \\
\text { available technologies }\end{array}$ & $\begin{array}{l}\text { "Green" technologies } \\
\text { Support will be provided for investment projects to introduce the best } \\
\text { available technologies in the environmental sphere. By the end of } \\
2024,6,900 \text { integrated environmental permits will be issued to all } \\
\text { facilities that have a significant negative impact on the environment } \\
\text { and relate to the areas of application of the best available technologies. } \\
\text { During the implementation of the national project, it is planned to } \\
\text { update } 51 \text { information and technical reference books on the best } \\
\text { available technologies. }\end{array}$ \\
\hline
\end{tabular}

The implementation of the national project was planned until 2024, but the pandemic made its own adjustments: the financing of the national project "Ecology" was reduced, and its implementation period was extended until 2030.

Since 2008, the All-Russian public Organization "Green Patrol" has been conducting research in the field of ecology and publishing environmental ratings of the subjects of the Russian Federation. The Volga Federal District takes the 4th place in the environmental rating out of eight possible ones. The leader in the Volga Federal District is the Republic of Chuvashia, the outsider is the Orenburg Region.

The results of the "National Environmental Rating of Regions" for the autumn of 2020 are presented in Table 3 [9]. 
Table 3. Environmental rating of the regions of the Volga Federal District (for the period 01.09.2020 $-30.11 .2020)[10]$.

\begin{tabular}{|c|c|c|c|c|c|c|c|}
\hline Subject & 总 & 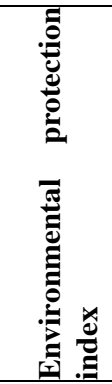 & 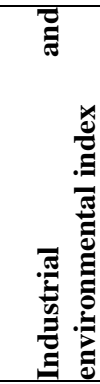 & 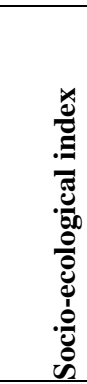 & 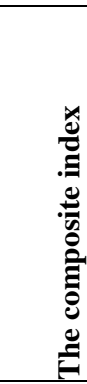 & 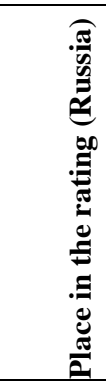 & 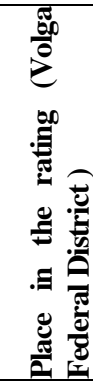 \\
\hline $\begin{array}{l}\text { Republic of } \\
\text { Chuvashia }\end{array}$ & 18300 & $61 / 39$ & $51 / 49$ & $81 / 19$ & $67 / 33$ & $7(-)$ & 1 \\
\hline $\begin{array}{ll}\text { Republic } \\
\text { Udmurtia }\end{array}$ & 42100 & $53 / 47$ & $52 / 48$ & $78 / 22$ & $65 / 35$ & $15(-3)$ & 2 \\
\hline $\begin{array}{l}\text { Ulyanovsk } \\
\text { region }\end{array}$ & 37300 & $54 / 46$ & $59 / 41$ & $75 / 25$ & $64 / 36$ & $17(-2)$ & 3 \\
\hline Perm Region & 160600 & $50 / 50$ & $60 / 40$ & $73 / 27$ & $63 / 37$ & $25(+3)$ & 4 \\
\hline $\begin{array}{l}\text { Republic of Mari } \\
\text { El }\end{array}$ & 23200 & $62 / 38$ & $45 / 55$ & $73 / 27$ & $63 / 37$ & $26(+4)$ & 5 \\
\hline Penza region & 43200 & $59 / 41$ & $42 / 58$ & $78 / 22$ & $63 / 37$ & $28(-2)$ & 6 \\
\hline $\begin{array}{l}\text { Republic } \\
\text { Tatarstan }\end{array}$ & 68000 & $47 / 53$ & $46 / 54$ & $79 / 21$ & $60 / 40$ & $38(-)$ & 7 \\
\hline $\begin{array}{l}\text { Republic } \\
\text { Mordovia }\end{array}$ & 26200 & $55 / 45$ & $39 / 61$ & $76 / 24$ & $60 / 40$ & $40(+4)$ & 8 \\
\hline Samara region & 53600 & $46 / 54$ & $57 / 43$ & $70 / 30$ & $60 / 40$ & $41(+4)$ & 9 \\
\hline Kirov region & 120800 & $47 / 53$ & $49 / 51$ & $72 / 28$ & $59 / 41$ & $46(-4)$ & 10 \\
\hline $\begin{array}{l}\text { Republic of } \\
\text { Bashkortostan }\end{array}$ & 143600 & $43 / 57$ & $53 / 47$ & $73 / 27$ & $58 / 42$ & $50(+2)$ & 11 \\
\hline $\begin{array}{l}\text { Nizhny } \\
\text { Novgorod region }\end{array}$ & 74800 & $40 / 60$ & $50 / 50$ & $74 / 26$ & $58 / 42$ & $53(+5)$ & 12 \\
\hline Saratov region & 100200 & $48 / 52$ & $48 / 52$ & $67 / 33$ & $56 / 44$ & $59(-2)$ & 13 \\
\hline Orenburg region & 124000 & $31 / 69$ & $41 / 59$ & $70 / 30$ & $50 / 50$ & $72(+2)$ & 14 \\
\hline
\end{tabular}

The environmental component of economic security is the most important category today not only of the regional economy, but also of ensuring the stability of the socioeconomic system as a whole. The environmental safety parameters of the region can be determined based on the assessment of the level of environmental risks (indicators). Let's analyze the above indicators on the example of the Kirov region (Table 4).

Table 4. The place of the Kirov region in the national environmental rating (for the period 01.09.2020 $-30.11 .2020)$ [11].

\begin{tabular}{|c|c|c|c|c|c|}
\hline Indicator & $+/-$ & Indicator & $+/-$ & Indicator & $+/-$ \\
\hline Atmosphere, air & -- & Habitat & +++ & $\begin{array}{c}\text { Industrial } \\
\text { environme } \\
\text { nt }\end{array}$ & - \\
\hline $\begin{array}{c}\text { Water resources, } \\
\text { water }\end{array}$ & ++ & Authorities & + & $\begin{array}{c}\text { Solid } \\
\text { household } \\
\text { waste }\end{array}$ & $\begin{array}{c}+++++++++ \\
+--\end{array}$ \\
\hline $\begin{array}{c}\text { Land resources, } \\
\text { soil }\end{array}$ & $\begin{array}{c}\text { No ratings } \\
\text { for this } \\
\text { period }\end{array}$ & Civil society & + & $\begin{array}{c}\text { Science } \\
\text { and } \\
\text { innovation }\end{array}$ & $\begin{array}{c}\text { No ratings } \\
\text { for this } \\
\text { period }\end{array}$ \\
\hline Specially & No ratings & nformation and & +++- & Environm & No ratings \\
\hline
\end{tabular}




\begin{tabular}{|c|c|c|c|c|c|}
\hline $\begin{array}{c}\text { protected natural } \\
\text { territories } \\
\text { (SPNT) } *\end{array}$ & $\begin{array}{c}\text { for this } \\
\text { period }\end{array}$ & $\begin{array}{c}\text { psychologist } \\
\text { climate }\end{array}$ & $\begin{array}{c}\text { ental } \\
\text { moderniza } \\
\text { tion }\end{array}$ & $\begin{array}{c}\text { for this } \\
\text { period }\end{array}$ \\
\hline Biodiversity & $\begin{array}{c}\text { No ratings } \\
\text { for this } \\
\text { period }\end{array}$ & $\begin{array}{c}\text { Education and } \\
\text { culture }\end{array}$ & +++ & $\begin{array}{c}\text { Products } \\
\text { and } \\
\text { services }\end{array}$ & $\begin{array}{c}\text { No ratings } \\
\text { for this } \\
\text { period }\end{array}$ \\
\hline Bioresource & +- & $\begin{array}{c}\text { Housing and } \\
\text { communal services }\end{array}$ & $\begin{array}{c}\text { No } \\
\text { ratings } \\
\text { for this } \\
\text { period }\end{array}$ & $\begin{array}{c}\text { Business } \\
\text { respon- } \\
\text { sibility }\end{array}$ & $\begin{array}{c}\text { No ratings } \\
\text { for this } \\
\text { period }\end{array}$ \\
\hline $\begin{array}{c}\text { Nature protection } \\
\text { index }\end{array}$ & $\begin{array}{c}\text { No ratings } \\
\text { for this } \\
\text { period }\end{array}$ & Law and order & ++ & $\begin{array}{c}\text { Industrial } \\
\text { waste }\end{array}$ & $\begin{array}{c}\text { No ratings } \\
\text { for this } \\
\text { period }\end{array}$ \\
\hline $\begin{array}{c}\text { Consolidated } \\
\text { environmental } \\
\text { rating of the } \\
\text { region }\end{array}$ & $47 / 53$ & Socio-ecological \\
index & $72 / 28$ & $\begin{array}{c}\text { Industrial } \\
\text { and } \\
\text { environ- } \\
\text { mental } \\
\text { index }\end{array}$ & 49/51 \\
\hline Region rating & \multicolumn{5}{|l}{$59 / 41$} \\
\hline
\end{tabular}

* Note: SPNT is an indicator that reflects the number and area of specially protected areas in the region, their state, events related to their protection, the level of funding, and various activities carried out on their territory. This indicator also shows violations of the security regime, natural disasters on the territory SPNT.

The loss of the Kirov Region's position in the environmental rating is due to the deterioration of environmental and industrial-environmental factors. For a number of indicators, there are simply no estimates, which also affects the final result (assessment).

The average Russian level of soil contamination with chemicals has been exceeded In the region $-21.3 \%$ of soil samples do not meet the hygienic standards for sanitary and chemical indicators. The excess of the hygienic standard for the average annual radon emission in the premises of operated residential and public buildings was registered.

The department revealed unsatisfactory results of water samples in the region on sanitary-chemical and microbiological indicators. According to parasitological indicators, the water in the selected samples meets the regulatory requirements in the region.

On the index of "garbage" tension of the Wasteconsulting group in the rating of regions, the Kirov region took 49th place, falling into the so-called yellow zone: the percentage of tension in the region is 54\%. The purpose of the index is to inform the authorities and society about the management and political risks that prevent the creation of a closed-loop economy in the country. In the yellow zone are those regions where there is a high risk of garbage protests.

The main source of pollution in the region is motor transport, which accounts for $56 \%$ of all pollutants. Also, manufacturing industries and electric power companies make a significant contribution to the air pollution of the region. The main part of emissions is general industrial emissions, carbon monoxide, sulfur dioxide, nitrogen oxides [12].

A number of measures are being taken within the framework of the «Clean Country» regional project to address environmental issues and to ensure the sustainable development of the region:

- development of the timber industry complex, traditional for the Kirov region, including reforestation

- stricter control over industrial enterprises in terms of emissions into the atmosphere, 
- transition to separate waste collection,

- creation of specially protected natural territories.

\section{Discussion}

According to experts (report of the World Economic Forum), the shift in focus to environmental issues was dictated by the pandemic and its consequences. In 2021, the main risks, according to experts, will be: infectious diseases and extreme natural phenomena associated with climate change [13].

The overall picture of global threats, according to the authors of the Global Risks 2020 Report, included:

geopolitical instability;

problems of economic development;

insufficient measures to address climate change;

negative impacts of biodiversity loss;

inefficient management of technology development;

failure of national health systems [5].

Over the past decade, environmental threats have come to the fore. For the first time in the last ten years of global risk research, the World Economic Forum has identified environmental threats in all positions in the top five risks by probability of occurrence and three positions in the top five risks by degree of impact. The usage of weapons of mass destruction and water supply crises were recognized as two other major risks in terms of impac [5].

Table 5. The degree of probability of global threats $[5,13]$.

\begin{tabular}{|l|l|}
\hline \multicolumn{1}{|c|}{$\mathbf{2 0 2 1}$} & \multicolumn{1}{c|}{$\mathbf{2 0 2 0}$} \\
\hline extreme weather & economic confrontations \\
\hline failure of climate actions & intra-national political polarization \\
\hline damage to the human environment & extreme heat waves \\
\hline infectious diseases & destruction of natural ecosystems \\
\hline loss of biodiversity & cyber attacks on infrastructure \\
\hline $\begin{array}{l}\text { concentration of power in the field of } \\
\text { digital technologies }\end{array}$ & protectionism in trade or investment \\
\hline digital divide & populist and nativist agendas \\
\hline severance of interstate relations & cyber attacks aimed at stealing money or data \\
\hline failure of cybersecurity & slowing growth in the largest economy \\
\hline crisis of the means of subsistence & uncontrolled fires \\
\hline
\end{tabular}

According to the rating of the main threats compiled by the WEF experts based on the "degree of impact" on people's lives in 2021, the second line after infectious diseases is occupied by problems related to climate change. This is followed by risks related to weapons of mass destruction, loss of biodiversity, natural resource crises, damage to human habitats, livelihood crises, extreme weather events, debt problems, and information technology infrastructure failures.

Among the current risks for the next two years, the authors of the study call infectious diseases, the crisis of livelihoods, digital inequality and the frustration of young people [13].

\section{Conclusions}

The challenges identified in the Global Risk Report should be addressed responsibly by all countries that adhere to the concept of sustainable development. At the same time, each 
country develops specific target indicators for sustainable development, taking into account the specifics of the country itself and its individual regions, taking into account economic, social and environmental aspects.

In Russia, a number of national projects are being implemented to achieve the SDG, including the national project "Ecology". The national project "Ecology" includes 10 federal projects, each of which includes projects developed and implemented taking into account the specifics of specific regions. A number of regional projects included in the national project "Ecology" have been developed in the Kirov region.

Within the framework of the regional project "Clean Country" of the national project "Ecology", it is planned to eliminate six landfills in the region in five years.

During the implementation of the "Clean Water" project, the reconstruction and modernization of water supply facilities will take place. The final goal of the project is to increase the quality water supply in the region to $91.7 \%$ in five years. The project will be financed by 1.469 billion rubles.

In 2019, the facility for the destruction of chemical weapons "Maradykovsky" in the village of Mirny, Kirov region, was redesignated as an enterprise for the processing, disposal and neutralization of waste of hazard classes I and II. The capacity of the facility will be up to 50 thousand tons per year, the commissioning is scheduled for 2023 .

The region has started switching to separate garbage collection since 2020. Currently, the Ministry of energy and housing of the Kirov region has developed a procedure for the Fwdt;faccumulation of housing and communal services, including their separate accumulation on the territory of the region, which is undergoing the approval procedure.

Specially protected natural territories will be created in five districts of the region, and it is also planned to update the regional Red Book. The development of ecological tourism and the protection of rare animal species in the region is planned to be implemented in the period 2019-2024 [12].

During the implementation of the project will establish protected areas in upper Kama, Vyatskopolyanskiy, Verkhoshizhemskiy, Svechinskiy and Belokholunitskiy districts of the region - Kama-Porishskiy taiga-bog complex, Kuligskiy floodplain, South-taiga complex of spruce-fir forests "Oshet"', " Interfluve Atcveja and Yuma" and taiga-bog complex "Svetloe". It is also planned to create a specially protected natural area of federal significance — the national park "Vyatka", the area of which will be 50 thousand hectares.

\section{References}

1. I.N. Rubanov, Regional east bulletin 2(62), 58- 69 (2014)

2. V.V. Glinsky, L.K. Serga, M.S. Khvan, Bulletin of the educational and methodical Association. Scientific-practical journal 6, 159-165 (2014)

3. N. Kataeva, I. Marakulina, Y. Snigireva, S. Barinov, MATEC Web of Conferences "International Science Conference SPbWOSCE-2017 "Business Technologies for Sustainable Urban Development" ", 01046 (2018)

4. Rankings. The overall performance of all 193 UN Member States, https://dashboards.sdgindex.org/static/countries/profiles/Russian\%20Federation.pdf

5. Global Risk Report - 2020, https://roscongress.org/materials/doklad-o-globalnykhriskakh-2020/

6. N. Kataeva, A. Sysolyatin, D. Starkova, A. Mokhov, International Scientific and Practical Conference "Environmental Risks and Safety in Mechanical Engineering" (ERSME-2020)

https://www.e3sconferences.org/articles/e3sconf/abs/2020/77/e3sconf_ersme2020_10008/e3sconf_ers me2020_10008.html 
7. A. Mottaeva, A. Ivashchenko, A. Ryattel, E3S Web of Conferences 164, 10038 (2020) https://doi.org/10.1051/e3sconf /202016410038

8. National environmental rating. Press release, https://greenpatrol.ru/sites/default/files/pictures/pressreliz_po_itogam_osen_2020_0.pdf

9. E. Karieva, L. Akhmetshina, A. Mottaeva, E3S Web of Conferences 217, 07008 (2020) https://doi.org/10.1051/e3sconf/202021707008

10. National environmental rating. Autumn 2020. Kirov region, https:/greenpatrol.ru/ru/regiony/kirovskaya-oblast

11. Environmental agenda in the Kirov region, https://davydov.in/nature/ekologicheskayapovestka-v-kirovskoj-oblasti/

12. L. Akhmetshina, A. Mottaeva, E3S Web of Conferences 210, 13034 (2020) https://doi.org/10.1051/e3sconf/2020210130349.

13. The report of the World Economic Forum named the greatest risks of 2021, https://tass.ru/obschestvo/10497941?keepThis=true\&TB_iframe=true\&height=500\&wi $\mathrm{dth}=1100 \&$ caption $=\mathrm{TACC} /$ 